\title{
Malic enzyme: its purification and characterization from Mucor circinelloides and occurrence in other oleaginous fungi
}

\author{
J. Savitha, J.P. Wynn* and C. Ratledge
}

Malic enzyme was purified 43-fold from Mucor circinelloides. The enzyme was dependent on $\mathbf{M g}^{2+}$ or $\mathbf{M n}^{2+}$ for activity, was not active with D-malate and had a $\mathrm{pH}$ optimum at 7.8. The apparent $K_{\mathrm{m}}$ values for malate and $\mathrm{NADP}^{+}$were $488 \mu \mathrm{M}$ and $41 \mu \mathrm{M}$ respectively. The $M_{\mathrm{r}}$ of the native enzyme was $160 \mathrm{kDa}$. Five metabolic analogues of malate: oxaloacetate, tartronic acid, 1-methylenecyclopropane trans-2,3-dicarboxylic acid, malonic acid and glutaric acid, were found to inhibit malic enzyme activity at $10 \mathrm{~mm}$. Four oleaginous fungi, Mucor circinelloides, Mortierella alpina, Mortierella elongata and Pythium ultimum, were also examined, all possessed a soluble malic enzyme, two also possessed a microsomal malic enzyme.

Key words: Fungi, malic enzyme, Mucor, oleaginicity.

Malic enzyme [malate dehydrogenase (decarboxylating) $\left(\mathrm{NADP}^{+}\right)(\mathrm{EC}$ 1.1.1.40)] catalyses the reaction

$$
\text { L-malate }+\mathrm{NADP}^{+} \longrightarrow \text { pyruvate }+\mathrm{NADPH}+\mathrm{CO}_{2} \text {. }
$$

Although malic enzyme has been detected in a number of fungi, its metabolic function remains somewhat unclear. In some fungi, malic enzyme has been reported to be involved primarily in pyruvate metabolism (Zink 1972; Zink \& Katz 1973; McCullough \& Roberts 1974); whereas in others it has also been implicated in the provision of NADPH for lipid biosynthesis and fatty acid desaturation (Evans \& Ratledge 1985; Kendrick \& Ratledge 1992).

In the oleaginous fungus, Mucor circinelloides, two isozymes of malic enzyme were detected, one soluble and the other membrane bound (Kendrick \& Ratledge 1992). A survey was then initiated to examine if the possession of malic enzyme, and in particular the microsomal form of this

J.P. Wynn and C. Ratledge are and J. Savitha was with the Department of Applied Biology, University of Hull, Hull HU6 7RX, UK. J. Savitha is now with the Department of Microbiology, Bangalore University, Bangalore 560056, India; fax. 01482465458 . Corresponding author. enzyme, was a common feature of oleaginous fungi. The results of this survey are presented in this communication.

Due to the uncertainty concerning the metabolic function of this enzyme in fungi, malic enzyme has been studied further. This communication also outlines the purification and characterization of malic enzyme from Mucor circinelloides.

\section{Materials and Methods}

Cultivation of Fungi

Fungi were cultivated in 11 vortex-aerated bottles at $30^{\circ} \mathrm{C}$. Mucor circinelloides (CBS 108.16), Mortierella alpina (CBS 210.32) and Mortierella elongata (NRRL 5513) were cultivated on the medium of Kendrick \& Ratiedge (1992). Pythium ultimum (IMI 342645) was grown on the medium of Vogel (1964) with sucrose as a carbon source. Mycelia were harvested by filtration after $56 \mathrm{~h}$, except Mucor circinelloides which was harvested after $24 \mathrm{~h}$, and washed with distilled water.

Fractionation of Fungal Mycelia

Washed fungal mycelia were suspended in $50 \mathrm{~mm}$ Tris/ $\mathrm{HCl}$ buffer ( $\mathrm{pH} 7.4$ ) containing $20 \mathrm{mM}$ magnesium acetate, $2 \mathrm{mM}$ benzamidine 
Table 1. Typical purification of malic enzyme from Mucor circinelloides.

\begin{tabular}{lcccc}
\hline Step & $\begin{array}{c}\text { Total } \\
\text { Activity } \\
(\mu \mathrm{mol} / \mathrm{min})\end{array}$ & $\begin{array}{c}\text { Specific } \\
\text { Activity }\end{array}$ & $\begin{array}{c}\text { Purification } \\
\text { (fold) }\end{array}$ & $\begin{array}{c}\text { Recovery } \\
(\%)\end{array}$ \\
$\begin{array}{l}\text { Crude extract } \\
\begin{array}{l}(1)\left(\mathrm{NH}_{4}\right)_{2} \mathrm{SO}_{4} \\
\text { precipitation }\end{array}\end{array}$ & 51.2 & 0.043 & 1.0 & 100 \\
$\begin{array}{l}\text { (2) Gel filtration } \\
\text { (Sephacryl S-200) }\end{array}$ & 27.3 & 0.105 & 2.4 & 53 \\
$\begin{array}{l}\text { (3) lon exchange } \\
\text { (DEAE sephadex A-50) }\end{array}$ & 8.4 & 0.272 & 6.3 & 16 \\
$\begin{array}{l}\text { (4) Affinity } \\
\text { chromatography } \\
\text { (Mimetic Green 1A6XL) }\end{array}$ & 7.1 & 0.882 & 21.0 & 14 \\
\hline
\end{tabular}

All steps were carried out at $4^{\circ} \mathrm{C}$. Phosphate buffers were used throughout, for steps (1) and (2) the buffer used was $20 \mathrm{mM}(\mathrm{pH} \mathrm{7.0)}$ for step (3), $100 \mathrm{mM}(\mathrm{pH} \mathrm{7.0)}$ and for step (4), $10 \mathrm{mM}(\mathrm{pH} 6.0)$. Between steps 2,3 and 4 the active fractions were concentrated by ultrafiltration using an Amicon Diaflow PM30 membrane.

and $1 \mathrm{~mm}$ dithiothreitol and disrupted by passage twice through a French press at $35 \mathrm{MPa}$. The homogenate was centrifuged at $12,000 \times \mathrm{g}$ for $10 \mathrm{~min}$ at $4^{\circ} \mathrm{C}$ and the resultant extract was ultracentrifuged at $100,000 \times \&$ for $1 \mathrm{~h}$ at $4^{\circ} \mathrm{C}$. This supernatant was retained as the soluble fraction and the resuspended pellet was termed the microsomal fraction.

Determination of Malic Enzyme Activity

The activity of malic enzyme was assayed using the method of Hsu \& Lardy (1969).

Purification of Malic Enzyme from Mucor circinelloides

Purification of the soluble malic enzyme from Mucor circinelloides was carried out in four stages: ( 1 ) ammonium sulphate precipitation between 50 and $60 \%$ saturation. (2) gel filtration using a Sephacryl S-200 column $(3 \times 20 \mathrm{~cm})$. (3) ion exchange chromatography using a DEAE Sephadex A-50 column $(1.5 \times 30 \mathrm{~cm})$, protein was eluted with a $\mathrm{NaCl}$ gradient $(50 \mathrm{mM}$ to $250 \mathrm{~mm}$ ). (4) affinity chromatography using a Mirnetic Green IA6XL column 'Affinity Chromatography Ltd. Ballasalla, Isle of Man, UK), malic enzyme activity was eluted with $1 \mathrm{M} \mathrm{NaCl}$.

Characterization of the Purified Enzyme

PAGE Electrophoresis. SDS-PAGE was carried out according to Hames (1985) using 7.5\% (w/v) acrylamide. Non-denaturing PAGE was carried out using the same protocol but with the omission of SDS. On the non-denaturing gels malic enzyme activity was visualized using the activity stain of Zink \& Katz (1973).

Determination of Molecular Mass. The molecular mass of the native enzyme was established using a Sephacryl S-200 column, calibrated using Blue Dextran, carbonic anhydrase $(29 \mathrm{kDa}), B S A$ $(66 \mathrm{kDa})$, alcohol dehydrogenase $(150 \mathrm{kDa})$ and $\beta$-amylase $(200 \mathrm{kDa})$.

Inhibitor Studies. The effects of various potential inhibitors were determined by their inclusion in the standard assay mixture.

Kinetic Studies. The apparent $K_{\mathrm{m}}$ values for $\mathrm{NADP}^{+}$and malate were calculated using a standard Lineweaver-Burk plot. The concentration of each substrate was varied in the assay mixture whilst the other was maintained in excess.

Reproducibility of Results

Unless otherwise indicated all values are average values calculated from three independently derived sets of data.

\section{Results and Discussion}

Purification of Malic Enzyme

Malic enzyme from Mucor circinelloides was purified 43fold. A typical purification profile is given in Table 1. As judged by SDS-PAGE, the final preparation was not homogeneous. The preparation contained four protein bands, two of which were minor bands of low molecular weight that could not be removed by subsequent isoelectric focusing. The two major bands on the SDS-PAGE represented two isozymes of malic enzyme: both bands reacted strongly with the malic enzyme activity stain on the non-denaturing gels. These two major bands of malic enzyme did not appear to be the result of proteolytic degradation of a single native protein during purification as the inclusion of protease inhibitors, benzamidine, PMSF and EDTA, did not prevent the appearance of the two bands.

The purified malic enzyme preparation was not completely homogeneous but it was devoid of contaminating enzymes: malate dehydrogenase, $\mathrm{NADP}^{+}$-dependent isocitrate dehydrogenase, glucose-6-phosphate dehydrogenase, pyruvate carboxylase, citrate synthase and pyruvate kinase.

Although the purification of malic enzyme was successful, the recovery of the enzyme was poor (only $2 \%$ ). This was due to apparent inactivation of the enzyme during the purification process. Although attempts were made to stabi- 
Table 2. Malic enzyme activity in oleaginous fungi

\begin{tabular}{lcc} 
Fungus & \multicolumn{1}{c}{$\begin{array}{c}\text { Malic enzyme activity } \\
(\mu \mathrm{mol} / \mathrm{min} . \mathrm{mg} \text { protein })\end{array}$} \\
\cline { 2 - 3 } & Soluble fraction & Microsomal fraction \\
Mucor circinelloides & 0.052 & 0.012 \\
Mortierella alpina & 0.040 & not detected \\
Mortierella elongata & 0.064 & not detected \\
Pythium ultimum & 0.120 & 0.019 \\
\hline
\end{tabular}

lize the enzyme by supplementation of buffers with either glycerol, dithiothreitol, PMSF, benzamidine or EDTA, these were unsuccessful.

\section{Characterization of Purified Malic Enzyme}

Kinetic studies. The apparent $K_{\mathrm{m}}$ values of malic enzyme for malate and $\mathrm{NADP}^{+}$were $488 \pm 81 \mu \mathrm{M}(\mathrm{n}=4)$ and $41 \pm 15$ ( $\mathrm{n}=3$ ) $\mu \mathrm{M}$, respectively. Malic enzyme activity was dependent on the presence of either $\mathrm{Mg}^{2+}$ or $\mathrm{Mn}^{2}$, was not detected when D-malate was the substrate and had a $\mathrm{pH}$ optimum at 7.8 in $0.1 \mathrm{M}$ Tris $/ \mathrm{HCl}$ buffer.

Molecular mass. The $M_{\mathrm{r}}$ of the native enzyme as determined by gel filtration chromatography was $160 \mathrm{kDa}$.

Inhibition studies. A selection of metabolic analogues were studied to assess their ability to inhibit malic enzyme. Five compounds: oxaloacetate, tartronic acid, I-methylenecyclopropane trans-2,3-dicarboxylic acid, malonic acid and glutaric acid were found to cause complete inhibition of malic enzyme at $10 \mathrm{~mm}$.

The effects of AMP, ADP and ATP on malic enzyme activity were investigated. Although all three had inhibitory effects to varying degrees at $10 \mathrm{~mm}$, these were unrealistic in vivo concentrations and at $3 \mathrm{~mm}$ no appreciable effect was observed. It seems unlikely therefore that malic enzyme activity in vivo is regulated by energy charge.

Malic Enzyme Activity in Other Oleaginous Fungi

All the fungi investigated in this study possessed a soluble malic enzyme whereas only two were found to possess a microsomal isoenzyme (see Table 2). The possession of a soluble malic enzyme has previously been confirmed for Entomorphathora exitalis, Conidiobolus nanodes and Aspergillus nidulans although none of these possessed a microsomal form of the enzyme. Thraustochytium aureum was found to be devoid of malic enzyme activity (Kendrick 1991).

\section{Acknowledgement}

IS gratefully acknowledges The Jawaharlai Nehru Memorial Trust for its financial help. JW is supported by a research grant (21.27.67) from the Biotechnology and Biological Sciences Research Council, UK.

\section{References}

Evans, C.T. \& Ratledge, C. 1985 Possible regulatory roles of ATP: citrate lyase, malic enzyme and AMP deaminase in lipid accumulation by Rhodosporidium toruloides. Canadian Journal of Microbiology 19, 1000-1005.

Hames, B.D. 1985 An introduction to polyacrýlamide gel electrophoresis of proteins. In Gel electrophoresis of proteins: A practical approach. Eds Hames, B.D. \& Rickwood, D. pp. 1-91 Oxford: IRL Press.

Hsu, R. \& Lardy, H.A. 1969 Malic enzyme. Methods in Enzymology 13, 230-235.

Kendrick, A.J. 1991 The fungal production of polyunsaturated fatty acids currently considered to be of dietetic importance. PhD Thesis, University of Hull, UK.

Kendrick, A. \& Ratledge, C. 1992 Desaturation of polyunsaturated fatty acids in Mucor circinelloides and the involvement of the novel membrane-bound malic enzyme. European joumal of Biochemistry 209, 667-673.

McCullough, W. \& Roberts, C.F. 1974 The role of malic enzyme in Aspergillus nidulans. FEBS Letters 41, 238-242.

Vogel, H. 1964 Distribution of lysine pathways in fungi. American Naturalist 98, 435-445.

Zink, M.W. 1972 Regulation of the two malic enzymes in Newrospora crassa. Canadian Joumal of Microbiology 18, 611-617.

Zink, M.W. \& Katz, J.S. 1973 Malic enzyme of Fusarium oxysporum. Canadian Journal of Microbiology 19, 1187-1196.

(Received in revised form 18 December 1995; accepted 29 January 1996) 